\title{
Roll Cage Design and Validation for a Rally Vehicle
}

The roll cage represents one of the most significant equipments for the personal protection in every sport car and in rally vehicles in particular. It is generally made of thin gauge pipes, joined together, to assemble a safety structure. This frame has to be designed in the way to absorb the kinetic energy during impacts reducing the risk of injuries for drivers and navigators. The design of an appropriate roll cage to be installed on a rally vehicle and its validation by Finite Elements methods represent the main motivation for this investigation. CAD frame was modelled by CATIA software using shell elements. Geometrical and material nonlinear FEM analysis was implemented by PAK code. Using experimental tests in displacement control conditions, critical forces on the structure were also determined. Numerical results were compared with experimental ones, permitting to refine the simulation model. Then, FEM provided the safety factor and all the information regarding the strength of acceptable materials. The CAD/FEM procedure, limiting the number of experimental tests, reduced cost and time requested for the design validation.

Keywords: Roll Bar, Safety Cage, Vehicle Safety, FEM Simulation, Strength Analysis, Design Validation.

\section{INTRODUCTION}

The roll cage (or sometime called safety cage) is a defending structure designed to protect the occupants of sport vehicles from rollovers, frontal crashes or other potential accidents of any kind and severity. When the car flips upside down, for example, the roll cage has to protect the roof of a car from crushing down, preventing the rider from getting stuck inside crushed metal. It also helps to stiffen the chassis, which is a desirable result in every racing application.

Since the '60, the roll cages have been largely used on rally cars, racing cars in general and, even, convertibles [1]. The efficiency of these protections must be certified by international associations and, only after strict controls they can be approved and fitted on racing cars [2]. The use on normal cars is prohibited and cannot therefore, either mount or approve.

There are many different roll cage designs, depending on the definite applications, hence diverse racing organizations have differing specifications and regulations. In particular, a World Rally Car is a racing automobile built in accordance with the specifications set by the International Automobile Federation (FIA), the international motorsports governing body and compete in the outright class of the World Rally Championship (WRC). The WRC specifications were introduced by the FIA in 1997 and periodically evolved, especially in terms of vehicle stiffness and passengers safety.

Received: May 2016, Accepted: June 2016

Correspondence to: Dr Ana Pavlovic

University of Bologna, Dept. of Industrial Engineering

Viale Risorgimento 2, 40136 Bologna, Italy

E-mail: ana.pavlovic@unibo.it

doi:10.5937/fmet1604398P

(C) Faculty of Mechanical Engineering, Belgrade. All rights reserved
As a consequence of these changes, all the protective devices, including the roll cages, have been increasingly evolving in complexity. Several designs have been proposed (Fig. 1) while a design validation is necessary.

The roll cage is generally built joining very rigid bars (also called roll-bars), made by high strength steel and able to support even the weight of the whole car without breaking. These frames are often called cells or survival cages for their outstanding resistance to all types of shocks: front, side or from tip-over.

Essentially, there are two types of cages, depending of the way roll-bars are connected to each other between welded and bolted.
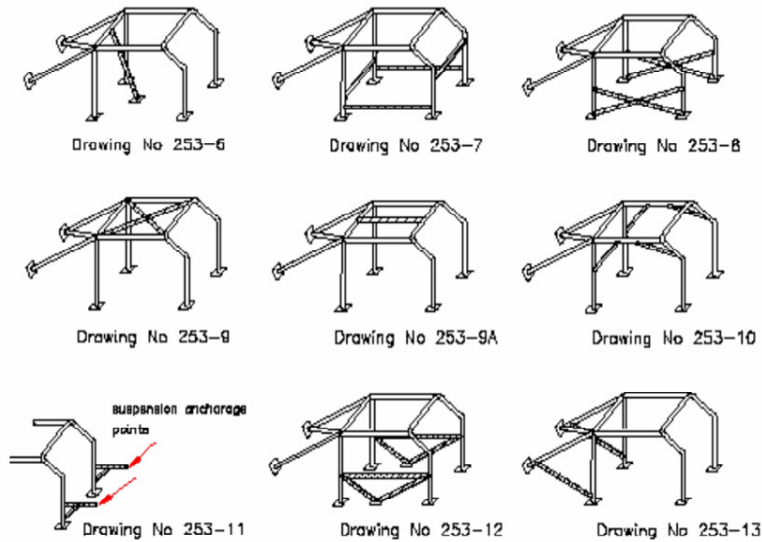

Figure 1: Typical configuration of roll cages in a rally car.

The bolted roll cage, that is bound to the machine frame with the bolts, is typically preferred where the use of the car is less burdensome and therefore the possibility of impact is reduced. On the contrary the welded roll cages are adopted where the possibility of accidents is very high and their severity can be fatal for the occupants [3]. Typical examples are the rally cars: in 
these patterns of roll-bar steel tubes are welded directly onto the chassis of the car and cannot be removed after their attachment, but ensure a very high safety level.

Notable experiences of roll cage design are reported in $[4,5,6]$, including the deployment of advanced approaches for accidents modelling [7, 8, 9, 10, 11].

According to a Total Quality approach and a Design for Safety specific priority [12], on the different stages of the vehicle design, it is possible to meet complex geometric changes in the roll cage shape. These variations can be related to miscellaneous aspects such as:

- optimisations in car design;

- improvements in safety;

- evolutions in race rules.

These design modifications can be effectively followed and checked by using Finite Elements (as in $[13,14,15,16,17])$. FEs permits, in fact, to quickly perform a high number of comparative analyses, reducing cost and time related to the experimental tests. Tests are limited to the final version of safety cage [18].

This specific investigation has been implemented by the following steps:

- Creating the 3D model of the roll cage

- Define the Finite Elements (FE) for discretization

- Define the material model

- Realisation of nonlinear quasi static simulation

- Comparing numerical and experimental results.

\section{DESIGN OF THE ROLL BAR STRUCTURE}

The design of every complex component follows few major concepts such as functionality, optimization, safety [19] and comfort. Even in the case of a protection device, as the roll cage, the design concepts remain strictly the same, but with a specific values.

The primary objective for a roll cage is to provide a three-dimensional protected space around the occupants, able to keep them safe. Then, as a secondary objective, the roll cage has to be easily mounted, low in weight and, possibly, low in cost.

These objectives can be achieved, at least in part, choosing a constructive material with high strength. In this case, advantages in terms of weight reduction are also possible, especially if powered by a specific design.

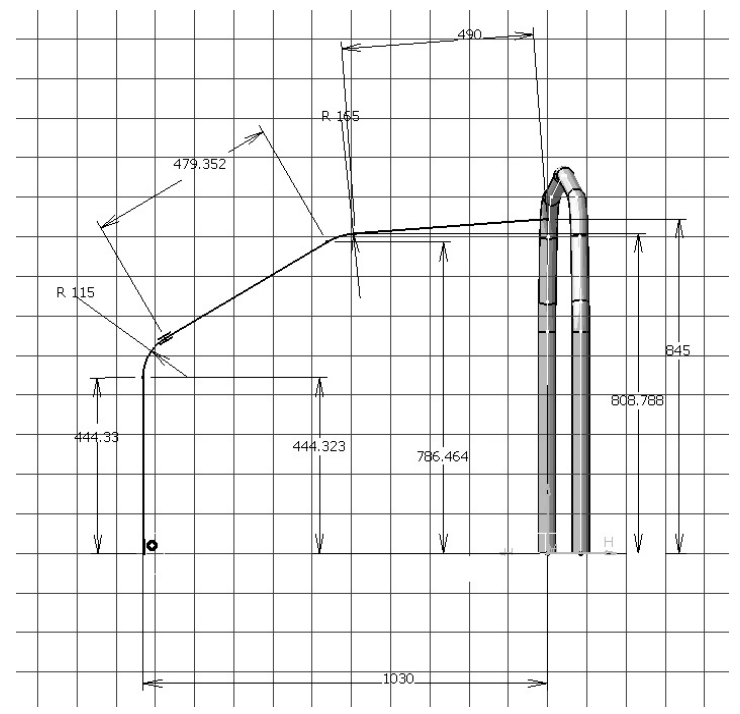

Figure 2: One step in modelling: design the main roll bar.
Entering in further details, according to FIA standards [2], safety cage is a multi-tubular structure installed in the cockpit and fitted close to the bodyshell, the function of which is to reduce the deformation of the bodyshell (chassis) in case of an impact.

Safety cage needs to contain basic components such as: the main roll bar that is transverse and near-vertical as a single piece tubular hoop located across the vehicle just behind the front seats (Fig. 2); the tube axis must be within one single plane; the front roll bar is similar to the main roll bar, but its shape follows the windscreen pillars and top screen edge; auxiliary roll bar that is near longitudinal and near to vertical single piece tubular hoop located along the right or left side of the vehicle, the front pillar of which follows the windscreen pillar and the rear pillar of which is near to vertical and located just behind the front seats; the transversal elements that are connecting the upper parts of the lateral roll bar; the diagram member that are transverse tube between top corners of the main roll bar, or one of the ends of the transverse member in the case of a lateral roll bar, and a the lower mounting point on the opposite side of the roll bar.

As a direct consequence of FIA standards, the roll cage was realized containing: basic arc, auxiliary arc, front arc, and two lateral arcs, several diagonal arcs and few lamellas. In particular, the basic arc that stands behind head of driver represents the main part of the structure. In the case of roll over it is exposed to the maximal load and displacement. This assembly has to prevent deformation on the basic arc and to reduce hurting of passengers that are in vehicle.

Furthermore, always according to the FIA standard, there are different ways of assembly the roll bars in the roll cage, but whichever is the case, the diagonal arcs have to be connected in the way not to provoke passengers hurting. Finally, the whole structure has to follow the shape of the vehicles.

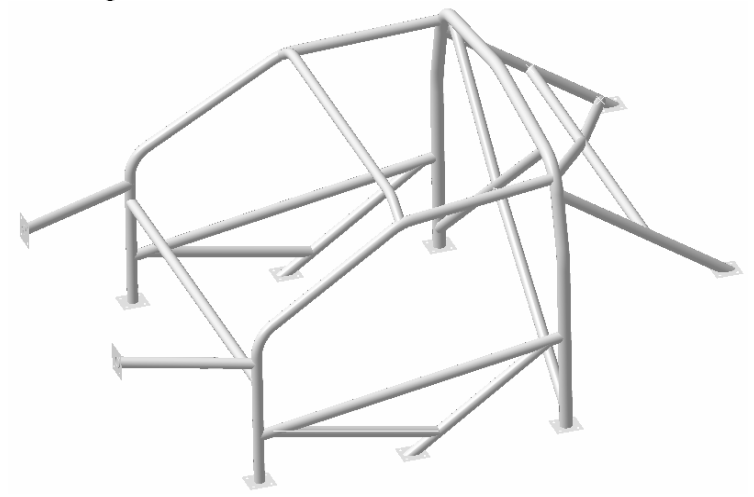

Figure 3: 3D model of the entire roll cage.

The roll cage design was realized using CATIA V.5. It represents one of the most popular software nowadays for the 3D modelling of complex structures with adaptive technology.

In particular, the tubular frame was realized by rolls with diameters of $38 \mathrm{~mm}$ or $45 \mathrm{~mm}$ and $2.5 \mathrm{~mm}$ of thickness. These tubes were modelled as thin shell elements in the way to create a parametric structure, facilitating future changes and rapid re-modelling of the safety cage (Fig. 3). To prevent faults in FEM modelling, during the design phase, it was necessary to 
be very precise with details and connections, making sure that no tube had breakthroughs or gaps.

\section{FEM ANALYSIS}

\subsection{FE discretisation}

The entire geometrical model was discretised by CATIA. Mesh was generated using isoparametric rectangular shell Finite Elements (Fig. 4). The FE analysis was realized using PAK [20] for the numerical calculation and FEMAP for the post-processing.

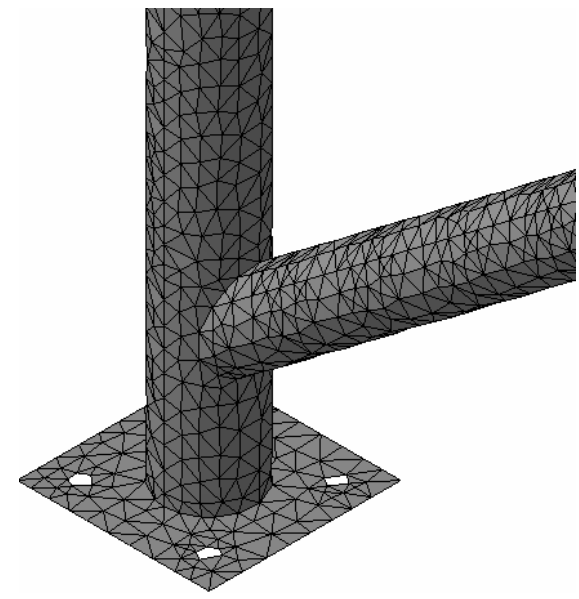

Figure 4: Discretisation of the basic arc by finite elements.

\subsection{Loads}

The roll cage was analysed considering several different configurations for loads (as intensity, direction, points of application) with the aim at better investigating its efficiency in term of protection respect to alternative hypothetical accidents.

Nevertheless the FE model was validated by comparing simulation predictions and experimental results in a single configuration: a quasi-static incremental application of a compressive load on the middle point of the basic arc. This simplified condition was preferred with the aim of permitting to realize a quick, easy and not destructive experiment. Additional details about the testing conditions are reported in the following section.

\section{SOLVING NONLINEAR EQUATION}

The CAD design was analysed by Finite Elements in PAK software [20] and focusing the attention on each critical point of the complex geometry. Nonlinear equations were used to model the inelastic behaviour.

The methods for solving nonlinear equations can be classified in two basic groups: incremental (in steps) and iterative (or Newton's) methods. Usually, it is used a mixed incremental/iterative procedure that includes a stress integration and the calculation of the tangent constitutive matrix. In Table 1, it is possible to realized that the stress integration and the calculation of the constitutive relations both represent key steps in an inelastic incremental/iterative analysis.

In general, it is referred to an error in the stress calculation as a consequence of approximations, like for the plastic strains as explained in the text which follows.
The algorithm should provide reasonable accuracy for large load increments and the error should rapidly diminish as the load step is decreased.

Table 1: Incremental and iterative solutions of equilibrium equation in inelastic analysis.

A. Initial conditions for step $\Delta \mathrm{t}$

$$
i=0 ;{ }^{t+\Delta t} U^{(0)}={ }^{t} U ;{ }^{t+\Delta t}{ }_{F}(0)={ }_{F}^{t} F ;{ }^{t+\Delta t} K^{(0)}={ }^{t} K
$$

B. Equilibrium iteration loop on the structural level

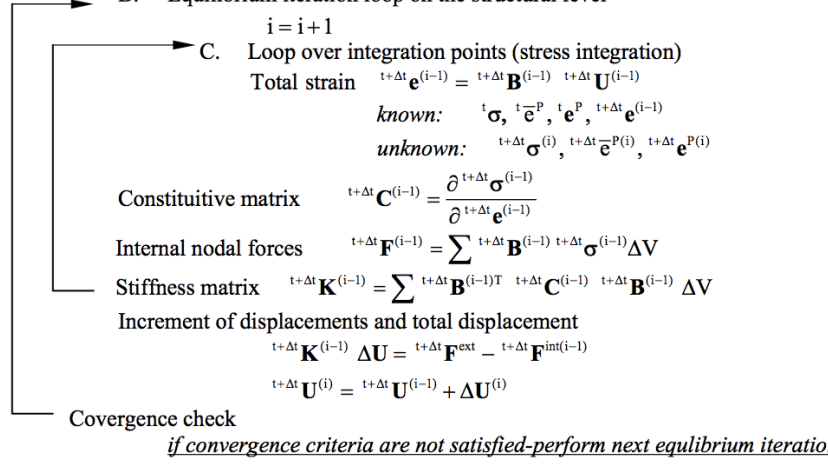$$
\mathrm{i}=\mathrm{i}+1
$$

Convergence was verified by the criterion of incremental inner energy.

$$
\Delta \mathbf{U}^{(\mathbf{i})}{ }^{\mathbf{T}}\left({ }^{\mathbf{t}+\Delta t} \mathbf{F}^{\text {ext }}-{ }^{\mathbf{t}+\Delta t} \mathbf{F}^{\text {int(i-1) }}\right) \leq \varepsilon_{\mathbf{E}} \Delta \mathbf{U}^{(1)}{ }^{\mathbf{T}}\left({ }^{\mathbf{t}+\Delta t} \mathbf{F}^{\mathrm{ext}}-{ }^{\mathbf{t}} \mathbf{F}^{\mathrm{int}}\right)(1)
$$

with $\varepsilon_{\mathrm{E}}$ the tolerance for energetic convergence criteria.

\subsection{Shell elements}

Four-nodes shell elements [21], represented in Fig. 2, are conveniently used for approaching safety problems and not only in automotive [22, 23]. Improvements in the response of the shell element were achieved through additional strain corresponding to generalized displacements that were incompatible between elements.

$$
\mathbf{u}_{\mathrm{i}}=\sum_{\mathrm{k}=1}^{\mathrm{N}} \mathbf{h}_{\mathrm{k}} \mathbf{U}_{\mathrm{i}}^{\mathrm{k}}+\frac{\mathbf{t}}{2} \sum_{\mathrm{k}=1}^{\mathrm{N}} \mathbf{a}_{\mathrm{k}} \mathbf{h}_{\mathrm{k}}\left(-\mathbf{V}_{2 \mathrm{i}}^{\mathrm{k}} \alpha_{\mathrm{k}}+\mathbf{V}_{\mathrm{li}}^{\mathrm{k}} \beta_{\mathrm{k}}\right)
$$

where $\boldsymbol{a}_{\boldsymbol{k}}$ is shell thickness, $h_{k}$ is interpolation function, $U_{i}$ is nodal displacement, $\alpha_{k}$ and $\beta_{k}$ are rotation in local coordinate system, $\mathbf{V}_{2 \mathrm{i}}^{\mathrm{k}}$ and $\mathbf{V}_{1 \mathrm{i}}^{\mathrm{k}}$ are basic vectors of local coordinate system in node k (Fig. 5).

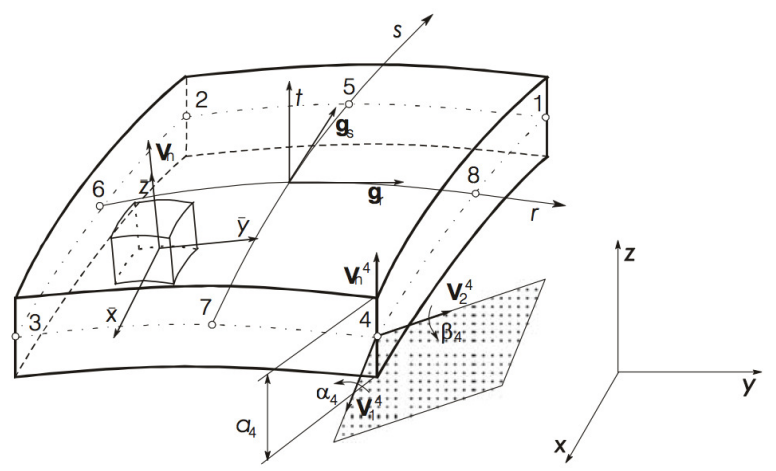

Figure 5: Shell type Finite Element.

\section{MODELLING THE MATERIALS}

\subsection{Materials}

Two alternative stainless steels, both for general engineering purposes, known in Europe with the codes EN1.0309 and EN1.0401, were investigated (Tab. 2). 
Table 2: Selection of materials

\begin{tabular}{|l|l|l|l|}
\hline Grade & Steel & Classification & Ref \\
\hline DX55D & 1.0309 & low carbon steel & EN10346 \\
\hline C15 & 1.0401 & non-alloy quality steel & EN10277 \\
\hline
\end{tabular}

Their chemical compositions and mechanical properties are strictly defined inside the EU standards (respectively EN 10346 [24] and EN 10277 [25]). Some characteristic values are also reported in Tab. 3 and 4.

The supremacy of EN 1.0401 steel in term of mechanical performance is evident.

Table 3: Chemical composition (\%).

\begin{tabular}{|l|c|c|c|c|c|c|}
\hline Steel & $\mathbf{C}$ & $\mathbf{S i}$ & $\mathbf{M n}$ & $\mathbf{P}$ & $\mathbf{S}$ & $\mathbf{T i}$ \\
\hline 1.0309 & $<0.12$ & $<0.5$ & $<0.6$ & $<0.1$ & $<0.045$ & $<0.3$ \\
\hline 1.0401 & $0.12-0.18$ & $<0.4$ & $0.3-0.8$ & $<0.045$ & $<0.045$ & - \\
\hline
\end{tabular}

Table 4: Mechanical properties.

\begin{tabular}{|c|c|c|c|c|}
\hline Steel & $\begin{array}{c}\text { Tensile } \\
\text { Strength }\end{array}$ & $\begin{array}{c}\text { 0.2\% proof } \\
\text { strength }\end{array}$ & $\begin{array}{c}\text { Min. elonga- } \\
\text { tion at fracture }\end{array}$ & $\begin{array}{c}\text { Brinell } \\
\text { hardness }\end{array}$ \\
\cline { 2 - 5 } & $\mathrm{MPa}$ & $\mathrm{MPa}$ & $\%$ & $\mathrm{HBW}$ \\
\hline 1.0309 & $270-370$ & $140-240$ & 30 & - \\
\hline 1.0401 & $500-800$ & 380 & 7 & $98-178$ \\
\hline
\end{tabular}

\subsection{Elastic-plastic material model}

These steels were modelled in PAK using a Von Mises elastic-plastic material model with mixed hardening [26-27].

In particular, the Yield Condition was defined as:

$$
{ }^{\mathrm{t}} \mathbf{f}_{\mathrm{y}}=\frac{1}{2}{ }^{\mathrm{t}} \hat{\mathbf{S}}^{\mathrm{T}} \cdot{ }^{\mathrm{t}} \hat{\mathbf{S}}^{\prime}-\frac{1}{3}{ }^{\mathrm{t}} \hat{\boldsymbol{\sigma}}_{\mathrm{y}}^{2}=0
$$

where $\mathbf{S}$ is deviatoric stress and $\hat{\sigma}_{\mathrm{y}}$ is the yield stress for the uniaxial stress state, (Fig. 6).
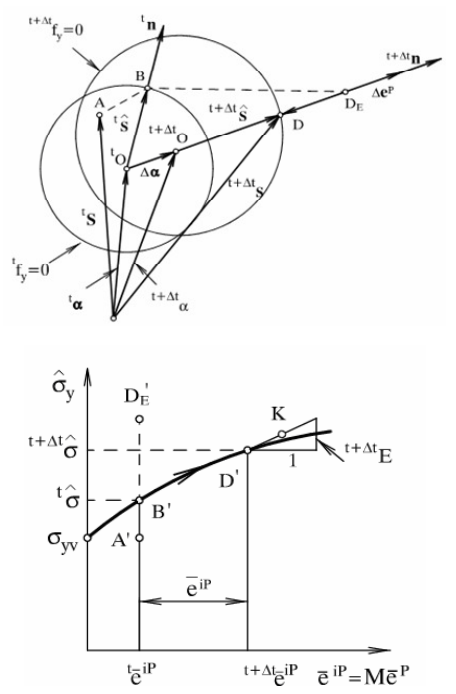

Figure 6: Stress condition on the yield surface at the beginning and the end of step.

\section{EXPERIMENTAL TEST}

Tests for design validation in the case of roll cages are commonly implemented loading the main roll bar or the auxiliary roll bar. The equipment for testing the roll cages in accordance with [2] is represented in Fig. 7. It consists in a servo-hydraulic press machine where loads are applied by a rectangular plate $(500 \times 200 \mathrm{~mm})$.

Since the protective response of the frame has to be integrally investigated, compressive tests have to be realized considering the entire roll cage structure.
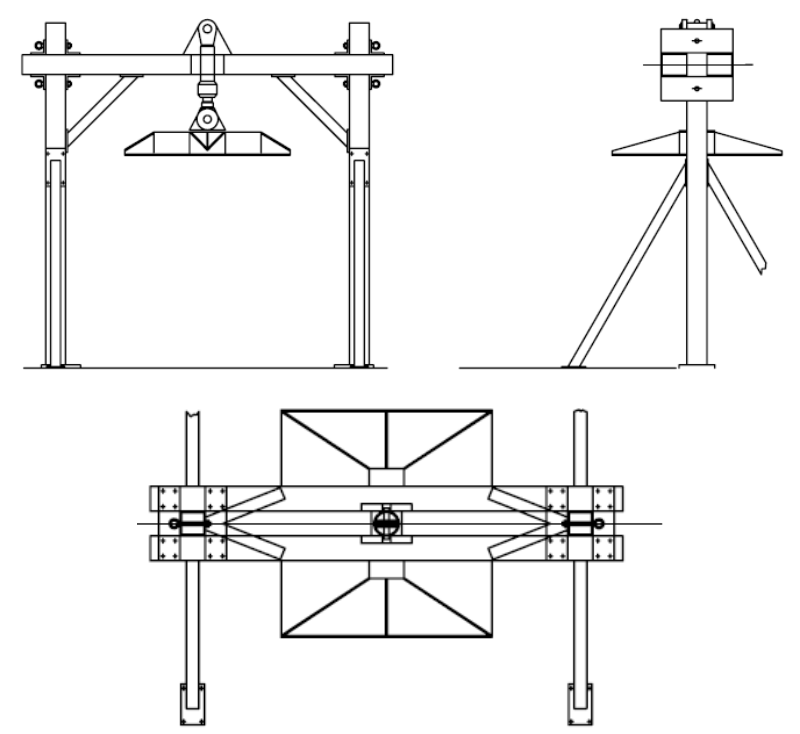

Figure 7: Equipment for roll cage testing [2].

In this case, tests were performed applying a force on the middle of the main roll bar and improving the load in intervals of $15 \mathrm{~s}$. Tests were realized in displacement control, measuring the consequential forces. 50 incremental steps, each one increasing the displacement for $1 \mathrm{~mm}$ were used. In accordance with [2], tests were terminated when displacement rose up to $50 \mathrm{~mm}$.

\section{RESULTS}

Numerical results, in terms of displacement and stress, are shown, respectively, in Fig. 8 and Fig. 9. The maximal plastic strain is in the area of application of the load where the yield stress is locally achieved. In all the other parts of the roll cage, the level of stress is several times lower than the material yield stress (Fig. 10).

From the experimental point of view the measured maximal load was $57.7 \mathrm{kN}$. It is noteworthy that, even if similar loads are not able to provoke significant damages on the roll cage, the limit of $50 \mathrm{~mm}$ has to be respected since larger displacements could seriously affect the safety of passengers.
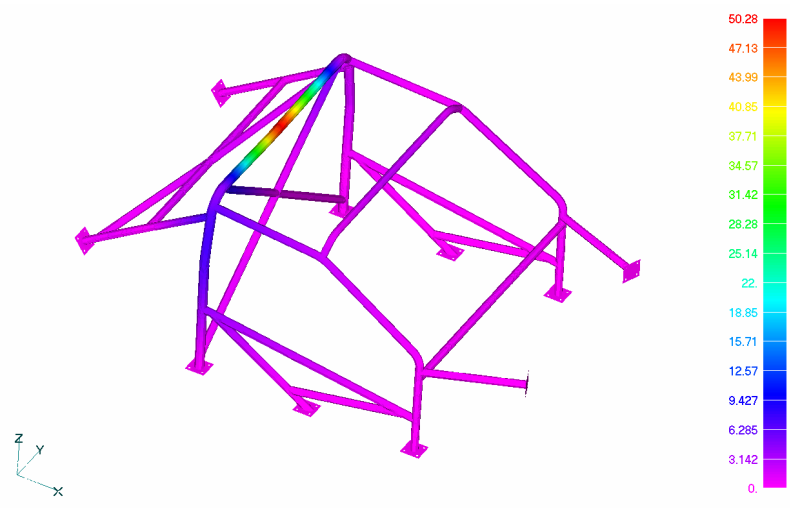

Fig. 8: Results in the field of displacements. 

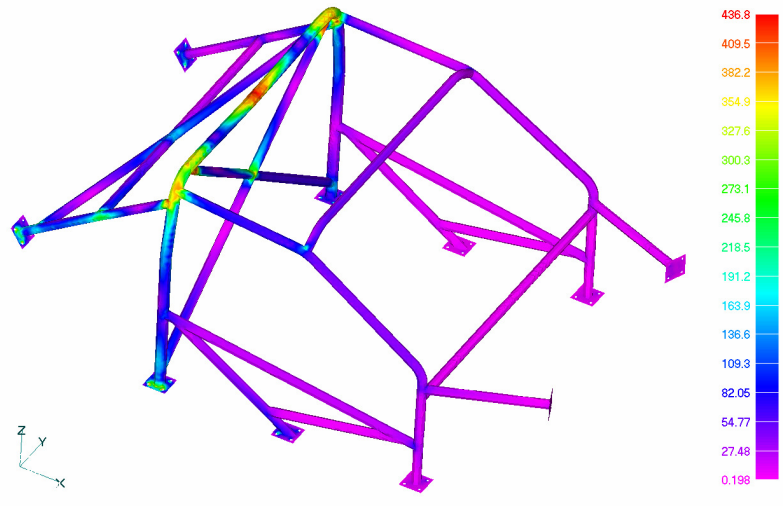

Fig. 9: Results in the field of effective stress.

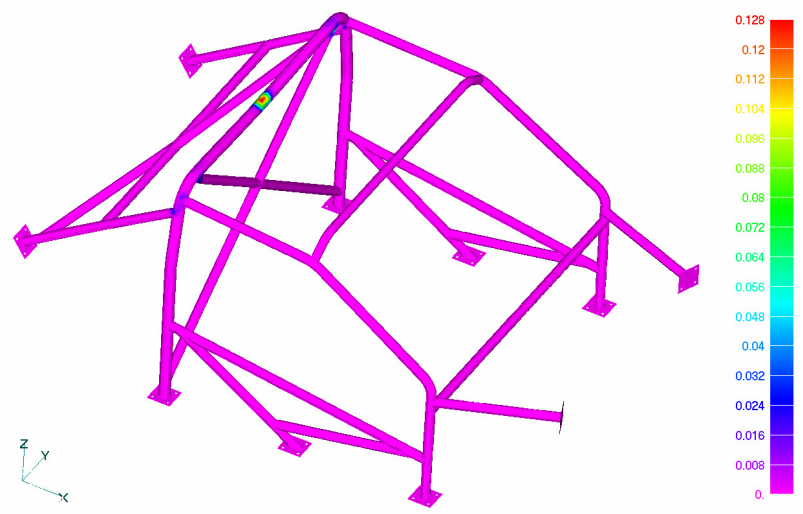

Fig. 10: Results in the field of plastic strain.

\subsection{Comparing materials}

The FE analysis started considering steel EU1.0309, a material representing a larger class of low carbon steels, preferred for manufacturing cheap roll cages. This material showed a significant plastic deformation. As evident in Figure 11, the material arrives at plasticity just after $12 \mathrm{~mm}$ of displacement. Then, the deformation continues without increasing the external force. This effect represents a potential risk for safety.

The other material, EU1.0401, with an yield stress $25 \%$ higher, showed better performances. According to the same Figure 11, a linear behaviour can be noticed until the upper limit of displacement is achieved. For that load, displacement is approximately $10 \mathrm{~mm}, 5$ time less than the ultimate displacement. It means that this material can sustain loads higher than the previous one.

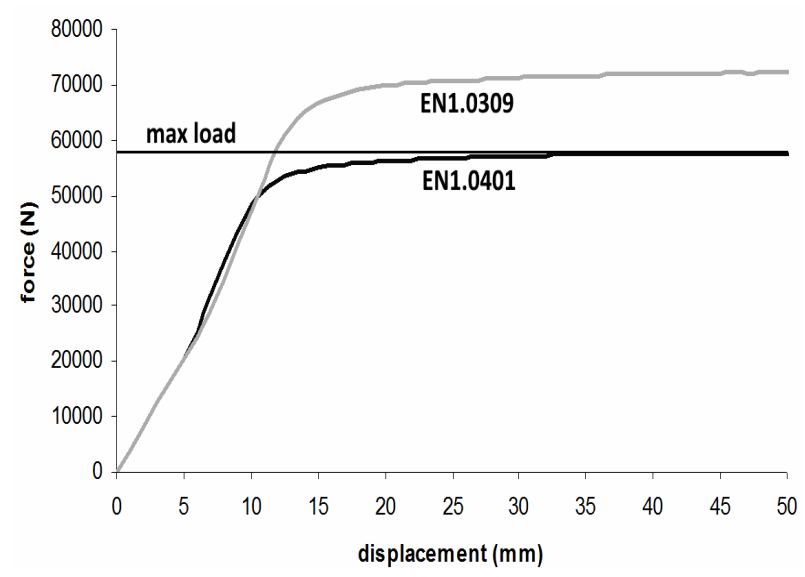

Figure 11: Force-displacement dependence.

\section{CONCLUSION}

The roll cage represents an indispensable expedient for protection of occupants during the rally race, providing additional strength to the car body frame. However, with the aim of assuring real benefits, a watchful design validation is necessary.

Experimental tests, realized in accordance with standards, surely represent a valid support for designers, but their use is limited by costs, time and complexity.

On the contrary, FEM simulations can prevent a wastefulness of resources focusing the test on the FE model validation. Then, by FE modelling and analysis, results can be obtained in short time, reducing costs and time from the idea to the installation.

This analysis specifically confirmed that material characteristics have a primary influence on the stiffness of vehicles. In particular, largely used low carbon steels (as EU1.0309) are often not able to satisfy the prescribed safety conditions ( $<50 \mathrm{~mm}$ of displacement) and quality steels (as EU1.0401) has to be preferred. Then, the roll cage can resist and risks of injury are reduced.

But FE analysis also permitted a structural optimization suggesting focused modifications in geometry as, for example, reinforcements limited to the main roll bar.

The final version of the roll cage, as designed, validated, developed and installed inside the rally car, is shown in Figure 12.

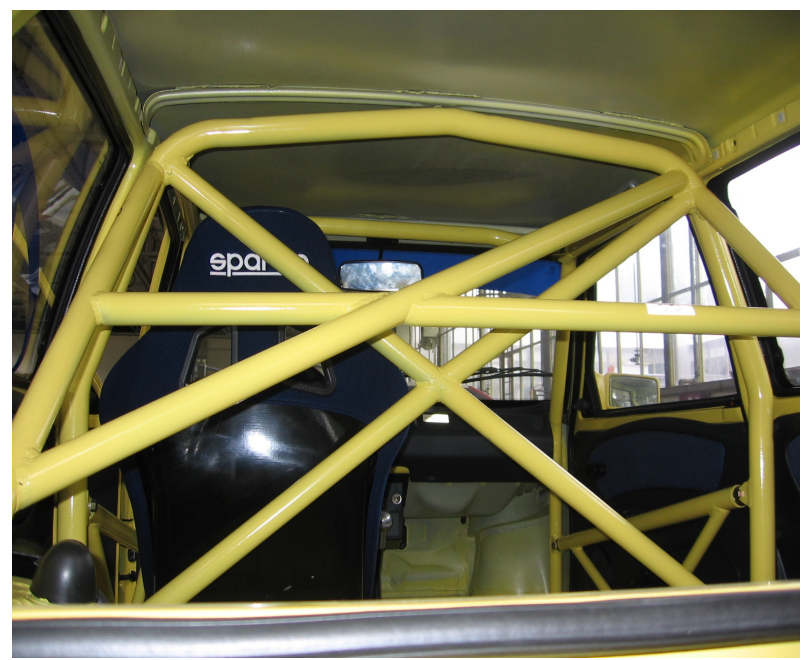

Figure 12: The final roll cage installed inside the rally car.

This research is realized as part of the AdriaHub collaborative project funded by the European Union (EU) inside the Adriatic IPA CBC Programme, an Instrument for the Pre-Accession Assistance (IPA) of neighbour countries of Western Balkan thanks to investment in Cross-Border Cooperation (CBC) aiming at a joint economic and social development [28].

\section{REFERENCES}

[1] Lawrence, M.: A to Z of Sports Cars, 1945-1990: The Encyclopaedic Guide to More Than 850 Marques and Thousands of Models (A-Z).. Motorbooks International, 1996.

[2] Federation International De L'Automobile (FIA), Safety Equipment (Groups N, A, R-GT), Appendix J - Art. 253, 04.12.2014. 
[3] Pouranvari, M. and Marashi, S. P. H.: Critical review of automotive steels spot welding: process, structure and properties. Science and Technology of welding and joining, Vol. 18, No. 5, pp. 361-403, 2013.

[4] Bernquist, J.: Safety cage design in the VOLVO XC90. American Iron and Steel Institute, Great Design in Steel Seminar, Livonia, MI. 2004.

[5] Naiju, C. D., et al.: Analysis of a Roll Cage Design against Various Impact Load and Longitudinal Torsion for Safety. Applied Mechanics and Materials, Vol. 232, 2012.

[6] Nassiopoulos, E. and Njuguna J.: Finite element dynamic simulation of whole rallying car structure: Towards better understanding of structural dynamics during side impact, 8th European LS-DYNA® Users Conference, Strasbourg, 23-24 May 2011.

[7] Nygren, A.: Injuries to Car Occupants-Some Aspects of the Interior Safety of Cars A study of a five-year material from an insurance company. Acta Oto-Laryngologica, Vol. 95, No. 395, pp. 1135, 1983.

[8] Robin, S.: HUMOS: human model for safety-a joint effort towards the development of refined human-like car occupant models. 17th international technical conference on the enhanced safety vehicle. 2001

[9] Eichberger, A., Schimpl, W., Werber, Ch. and Steffan, H.: A new crash test configuration for car-tocar frontal collisions with small lateral overlap, International Journal of Crashworthiness Vol. 12, No. 2, pp. 93-100, 2007.

[10] Teng, T. L., Chang, K. C. and Nguyen, T. H.: Crashworthiness evaluation of side-door beam of vehicle. Technische Mechanik, Vol. 28, No. 3-4, pp. 268-278, 2008.

[11] Ramon-Villalonga, L., and Enderich, Th.: Advanced Simulation Techniques for Low Speed Vehicle Impacts. Proceedings of 6th LS-DYNA, 2007.

[12]Fragassa, C., Pavlovic, A. and Massimo, S.: Using a Total Quality Strategy in a new Practical Approach for Improving the Product Reliability in Automotive Industry, International Journal for Quality Research, Vol. 8, N. 3, pp. 297-310, 2014.

[13] McKenzie, G.: Side impact crashworthiness of a world rally car roll cage, 2007.

[14]Luque, P., Mántaras, D. A. and Pello A.: Race car chassis optimization using the finite element method, multi-body dynamic simulation and data acquisition. Proceedings of the Institution of $\mathrm{Me}$ chanical Engineers, Part P: Journal of Sports Engineering and Technology: Doi.1754337112444517, 2012.

[15]Calienciug, A. and Radu, G. N.: Design and FEA crash simulation for a composite car bumper, Bulletin of the Transilvania University of Braşov Series III: Mathematics, Informatics, Physics, Vol. 5, No. 54, pp. 1-12, 2012.

[16] Chandra, S., Fassmann, W., Ruoti, C., Stubbs, K., Jensen, C. and Bala, S.: Crash Simulation of PACE Formula-1 Race Car. Computer-Aided: Crash Simulation of PACE Formula-1 Race Car, Com-
puter-Aided Design \& Applications, pp. 31-46, 2011.

[17] Mahendra, H. M., Praveen Kumar, B. S., Puttaswamaiah, S. and Prakash, G.S: Design and crash analysis of a rollcage for formula SAE race car, International Journal of Research in Engineering and Technology, Vol. 03, No. 07, pp. 126-130, 2014.

[18] Patalak, J. and Gideon, T.: Quasi-Static Testing of Tubular Roll Cage and Stock Car Chassis Joints. SAE Technical Paper, No. 2011-01-1105, 2011.

[19] Pavlovic, A. and Fragassa, C.: General considerations on regulations and safety requirements for quadricycles, International Journal for Quality Research, Vol. 9, No.4, pp: 657-674, 2015.

[20] Kojic, M., Slavkovic, R., Zivkovic, M. and Grujovic, N.: PAK-S Program for FE Structure Analysis, Faculty of Mechanical Engineering in Kragujevac Edition, Kragujevac, 1998.

[21] Slavkovic, R., Zivkovic, M. and Kojic, M.: Enhanced 8-node three-dimensional solid and 4-node shell elements with incompatible generalized displacement, Communication of numerical methods in engineering, Vol. 10, pp. 699-709, 1994.

[22] Pavlovic, A. and Fragassa, C.: Analysis of flexible barriers used as safety protection in woodworking. Journal of Quality Research, Vol.10, No.1, pp.71$88,2016$.

[23] Pavlovic, A. and Fragassa, C.: Numerical modelling the ballistic impacts on flexible curtains used as safety protection in woodworking. Proceedings of the Institution of Mechanical Engineers, Part C: Journal of Mechanical Engineering Science. DOI: 10.1177/0954406216646401, 2016.

[24]BS EN 10346:2009, Continuously hot-dip coated steel flat products. Technical delivery conditions

[25]BS EN 10277-2:2008, Bright steel products. Technical delivery conditions. Steels for general engineering purposes.

[26] Kojic, M., Slavkovic, R., Zivkovic and M., Grujovic N.: Finite Element Method I- linear analysis, Faculty of Mechanical Engineering in Kragujevac (ed.), Kragujevac, Serbia, 1998.

[27] Kojic, M. and Nathe, K.J.: Inelastic Analysis of Solids and Structures, Springer-Verlag, 2005.

[28] Savoia, M., Stefanovic, M. and Fragassa, C.: Merging Technical Competences and Human Resources with the Aim at Contributing to Transform the Adriatic Area in a Stable Hub for a Sustainable Technological Development, International Journal of Quality Research, Vol.10, No. 1, pp.1-16, 2016.

\section{ДИЗАЈН И ПРОЦЕНА ЗАШТИТНОГ КАВЕЗА ЗА РЕЛИ ВОЗИЛА}

\section{А. Павловић, М. Живковић}

Заштитни кавез представља један од најзјачајнијих делова опреме за личну заштиту путника на сваком спортском аутомобилу а посебно на рели возилима. Углавном је направљен од танких граничних цеви, спојени заједно, на начин да оформе сигурносну 
структуру. Овај оквир мора бити осмишљен тако да апсорбује кинетичку енергију током удара, смањује тиме ризик од повреда како за возача тако и за сувозача. Дизајн одговарајућег кавеза који је потребан да буде инсталиран на рели возилу и његова валидација методом коначних елемената представља главни мотив овог рада. CAD оквир је моделиран CATIA софтвером користећи елементе типа љуска. Анализа геометријске и материјалне нелинеарности је реализована коришћењем софтвера РАК. Користећи експерименталне тестове у контролисаним условима, одређена је максимална сила за коју усавршавање нумеричког модела. Нумерички резултати су упоређени са експерименталним, дозвољавајући тиме усавршавање нумеричког модела. Затим, анализом коначних елемената обезбеђени су фактор сигурности и све инфорације о јачини прихватљивих материјала. CAD/FEM поступак ограничава број експерименталних испитивања, смањује трошкове и време потребно за процену пројектних решења. 